\title{
Uji Daya Hambat Rebusan Daun Kitolod (Hippobroma longiflora) Terhadap Pertumbuhan Staphylococcus aureus
}

\section{Inhibitory Test of Kitolod (Hippobroma Longiflora) Leaves Decoction on The Growth of Staphylococcus aureus}

\author{
Handayani Puji Hastuti ${ }^{1}$, Ardy Prian Nirwana ${ }^{1}$ \\ ardypriannirwana@stikesnas.ac.id \\ ${ }^{1}$ Program Studi DIII Teknologi Laboratorium Medis, Sekolah Tinggi Ilmu Kesehatan Nasional \\ Surakarta \\ Riwayat Artikel: Dikirim Desember 2020; Diterima Februari 2021; Diterbitkan Maret 2021
}

\begin{abstract}
Abstrak
Escherichia coli merupakan bakteri Gram negatif berbentuk batang, mampu Konjungtivitis adalah peradangan pada konjungtiva. Salah satu bakteri penyebab konjungtivitis paling sering adalah Staphylococcus aureus. Hippobroma longiflora banyak digunakan oleh masyarakat tradisional untuk mengobati gangguan mata seperti konjungtivitis karena memiliki zat antimikroba seperti flavonoid, saponin, dan alkaloid. Penelitian ini bertujuan untuk mengetahui zona radikal yang dapat terbentuk dari rebusan daun H.longiflora terhadap pertumbuhan S.aureus. Metode penelitian ini adalah deskriptif eksperimental. Teknik sampling yang digunakan quota sampling. Penelitian menggunakan kontrol negatif aquades steril dan kontrol positif kloramfenikol $30 \mu \mathrm{g}$. Rebusan daun $H$. longiflora dapat menghambat pertumbuhan S. aureus ditunjukkan dengan hasil yang didapatkan terbentuk zona radikal dari masing-masing variasi konsentrasi $20 \%, 40 \%, 60 \%, 80 \%$, dan $100 \%$ secara berturut-turut adalah $6,18 \mathrm{~mm}, 6,23 \mathrm{~mm}, 6,68 \mathrm{~mm}, 7,20$ $\mathrm{mm}$ dan $8,18 \mathrm{~mm}$.

Kata kunci: Uji daya hambat, konjungtivitis, kitolod, Staphylococcus aureus
\end{abstract}

\begin{abstract}
Conjunctivitis is inflammation of the conjunctiva. One of the bacteria that causes conjunctivitis most often is Staphylococcus aureus. Hippobroma longiflora is widely used by traditional people to treat eye disorders such as conjunctivitis because it has antimicrobial substances such as flavonoids, saponins, and alkaloids. This study aims to determine the radical zones that can be formed from the decoction of $\mathrm{H}$. longiflora leaves against the growth of S.aureus. This research method is descriptive experimental. The sampling technique used was quota sampling. This study used a negative control with sterile distilled water and a positive control for $30 \mu \mathrm{g}$ chloramphenicol. The decoction of $\mathrm{H}$. longiflora leaves can inhibit the growth of $S$. aureus as indicated by the results obtained that form a radical zone of each concentration variation of $20 \%, 40 \%, 60 \%, 80 \%$, and $100 \%$ respectively $6.18 \mathrm{~mm} .6 .23 \mathrm{~mm}, 6.68 \mathrm{~mm}$, $7.20 \mathrm{~mm}$ and $8.18 \mathrm{~mm}$.
\end{abstract}

Keywords: Inhibitory test, conjunctivitis, kitolod, Staphylococcus aureus 


\section{Pendahuluan}

Mata merupakan salah satu organ yang memiliki peranan penting sebagai indra penglihatan (Insani dkk, 2017). Mata juga merupakan organ yang rentan terhadap infeksi. Salah satu infeksi mata yang sering dijumpai adalah konjungtivitis (Abdurrauf, 2016).

Bakteri yang menyebabkan konjungtivitis diantaranya yaitu Haemophilus influenzae, Staphylococcus aureus, Streptococcus pneumoniae dan Pseudomonas aeruginosa (Jawetz et al, 2013). Salah satu bakteri penyebab onjungtivitis paling sering adalah Staphylococcus aureus dengan tingkat keparahan yang bervariasi (Septiani dkk, 2017).

Staphylococcus aureus merupakan penyebab konjungtivitis bakterial kronik dan neonatal konjungtivitis yaitu konjungtivitis yang terjadi dalam empat minggu setelah kelahiran (Richards et al, 2010). Konjungtivitis bakteri dapat diobati dengan antibiotik tunggal seperti neospirin, basitrasin, gentamisin, kloramfenikol, tobramisin, eritromisin, dan sulfa selama 2-3 hari (Ilyas dkk, 2014).

Ketertarikan masyarakat Indonesia terhadap penggunaan obat - obatan herbal memicu munculnya berbagai produk pengobatan dari bahan alam yang dipercaya lebih aman dengan tingkat efek samping rendah serta kebutuhan akan adanya senyawa obat baru untuk menangani penyakit - penyakit infeksi yang ditimbulkan oleh bakteri patogen multiresisten dan terapi penyakit kronik (Malik dkk, 2014).

Kitolod $(H$. longiflora) dapat digunakan sebagai obat tradisional untuk mengobati gangguan mata seperti mata gatal, merah (konjungtivitis), katarak, dan mengeluarkan kotoran (Malik dkk, 2014). H. longiflora memiliki efek sebagai antibakteri terhadap konjungtivitis karena mengandung zat bioaktif yaitu zat yang termasuk metabolit sekunder yang bersifat aktif secara biologis, diantaranya senyawa alkaloid, flavonoid, dan saponin (Dalimartha, 2008). Menurut Kuswiyanto (2016), ada beberapa faktor yang mempengaruhi kinerja antimikrobial, diantaranya adalah konsentrasi atau intensitas zat antimikrobial, jumlah mikroorganisme, suhu, spesies mikroorganisme, adanya bahan organik, dan $\mathrm{pH}$.

Penelitian ini bertujuan untuk mengetahui apakah rebusan daun Hippobroma longiflora mampu membentuk zona radikal terhadap Staphylococcus aureus dan apakah zona radikal yang terbentuk pada masing-masing variasi konsentrasi rebusan daun Hippobroma longiflora mampu melebihi kontrol positif

Batasan dalam penelitian ini adalah besaran daya hambat rebusan daun Hippobroma longiflora terhadap pertumbuhan Staphylococcus aureus. Manfaat penelitian ini adalah sebagai berikut : 1) Memberikan informasi mengenai uji daya hambat daun $H$. longiflora terhadap $S$. aureus, sehingga diharapkan dapat menggali potensi antimikroba dari alam. 2) Menambah referensi di bagian mikrobiologi. 3) Memberikan informasi mengenai kegunaan daun $H$. longiflora sehingga diharapkan dapat memanfaatkan tanaman sebagai obat khususnya saat terjangkit penyakit mata.

\section{Metode Penelitian}

Penelitian ini menggunakan desain penelitian deskriptif eksperimental untuk mengetahui daya hambat dari rebusan daun $H$. longiflora terhadap pertumbuhan bakteri $S$. aureus dengan menggunakan metode difusi cakram yang dilakukan di Laboratorium Bakteriologi STIKES Nasional pada bulan Oktober 2019 sampai dengan Februari 2020.

\section{Sampel Penelitian}

Sampel dalam penelitian ini adalah rebusan daun $H$. longiflora yang diambil dari Kabupaten Karanganyar dan telah dibuat dalam berbagai konsentrasi.

\section{Variabel Penelitian}

Variabel terikat dalam penelitian ini adalah daya hambat Staphylococcus aureus, sedangkan variabel bebas dalam penelitian ini adalah rebusan daun $H$. longiflora dalam berbagai variasi konsentrasi.

\section{Teknik Sampling}

Teknik sampling yang digunakan dalam Karya Tulis Ilmiah ini adalah quota sampling. Daun $H$. longiflora segar dan bersih diambil dari wilayah Kabupaten Karanganyar.

\section{Sumber Data}

Data primer didapatkan secara langsung dari uji daya hambat rebusan daun $H$. longiflora terhadap $S$. aureus yang penelitiannya dilakukan di Laboratorium Bakteriologi STIKES Nasional. 


\section{Tahapan Penelitian \\ Karakterisasi Staphylococcus aureus}

1. Hari I :

Lakukan penyuburan sampel biakan murni $S$. aureus di media BHI secara aseptis ke dalam media BHI, inkubasi pada suhu $37^{\circ} \mathrm{C}$ selama 24 jam.

2. Hari II :

Inokulasikan secara aseptis biakan $S$. aureus dari media BHI ke media BAP secara goresan, inkubasi pada suhu $37^{\circ} \mathrm{C}$ selama 24 jam.

3. Hari III :

a. Pengamatan morfologi koloni $S$. aureus pada media BAP.

b. Dilakukan pengecatan Gram menurut (Dewi, 2013)

1) Buat preparat dari biakan bakteri sebanyak 2-3 ose secara aseptis pada obyek glass kemudian kering anginkan, fiksasi 2-3 kali diatas nyala api.

2) Genangi preparat dengan gram $A$, biarkan 2 menit, buang sisa cat, bilas dengan air mengalir kemudian genangi preparat dengan gram B selama 30 detik, buang sisa cat, bilas dengan air mengalir.

3) Decolorisasi preparat dengan gram $C$ sampai warna luntur, bilas dengan air mengalir, selanjutnya genangi preparat dengan gram D selama 2 menit, buang sisa cat, bilas dengan air mengalir, kering anginkan, tetesi emersi oil, dan periksa di bawah mikroskop dengan perbesaran 1000x.

4) Morfologi bakteri terlihat berbentuk kokus berwarna ungu dengan susunan bergerombol.

c. Uji Katalase (Dewi, 2013)

1) Siapkan obyek glass yang kering dan bebas lemak.

2) Diletakkan suspensi bakteri pada obyek glass dengan ose steril

3) Ditetesi dengan $\mathrm{H} 2 \mathrm{O} 23 \%$.

4) Hasil positif ditandai dengan terbentuknya gelembung udara.

d. Dimbil 1 ose koloni dari media BAP secara aseptis, diinokulasikan ke media NA miring dan media MSA, diinkubasi pada suhu $37^{\circ} \mathrm{C}$ selama 24 jam.
4. Hari IV :

a. Amati pigmen S.aureus yang terbentuk pada media NA miring. S.aureus mengahasilkan pigmen kuning emas.

b. Amati fermentasi yang terjadi pada media MSA. Pada uji manitol $S$. aureus memfermentasi manitol yang ditandai dengan terjadinya perubahan warna media dari merah menjadi kuning.

c. Uji Koagulase (Dewi, 2013)

1) Siapkan obyek glass yang bersih dan bebas minyak.

2) Di letakkan suspensi bakteri.diatas obyek glass dengan menggunakan ose steril

3) Ditetesi dengan plasma sitrat secara aseptis.

4) Hasil positif ditandai dengan terbentuknya aglutinasi.

\section{Pembuatan rebusan daun $H$. longiflora} (Fatmalia dan Dewi, 2018)

Daun $H$. longiflora yang akan digunakan dicuci terlebih dahulu dengan menggunakan aquadest steril, kemudian tiriskan. Setelah itu dipotong kecil-kecil dan ditimbang sebanyak 100 gram kemudian dimasukkan ke dalam becker glass dan ditambahkan aquadest steril sebanyak $100 \mathrm{ml}$ kemudian direbus selama 10 menit dengan suhu $90^{\circ} \mathrm{C}$ (konsentrasi 100\%). Saring rebusan tersebut dengan menggunakan kertas saring, kemudian dibuat variasi konsentrasi 20\%, 40\%, 60\%, dan 80\% dengan cara pengenceran dari konsentrasi 100\%.

Rumus perhitungan pengenceran:

$\mathrm{M} 1 \mathrm{xV} 1=\mathrm{M} 2 \mathrm{xV} 2$

Keterangan:

M1 : konsentrasi awal

V1 : volume konsentrasi awal

M2 : konsentrasi variasi

$\mathrm{V} 2$ : volume konsentrasi variasi

Uji Fitokimia (Nirwana, 2015)

1. Pemeriksaan Flavonoid

Rebusan daun $H$. longiflora sebanyak $2 \mathrm{ml}$ dimasukkan ke dalam tabung reaksi, lalu ditambahkan serbuk $\mathrm{Mg}$ dan $2 \mathrm{ml}$ larutan HCL 2N. Perubahan warna larutan menjadi warna merah jingga sampai merah menunjukkan adanya senyawa flavonoida. 
2. Pemeriksaan Saponin

Sebanyak $2 \mathrm{ml}$ sampel rebusan daun $H$. longiflora dimasukkan kedalam tabung reaksi kemudian ditambahkan $10 \mathrm{ml}$ aquadest, dikocok selama 10 detik. Hasil uji positif jika timbul busa stabil selama 10 menit.

3. Pemeriksaan Alkaloid Sebanyak $3 \mathrm{ml}$ sampel rebusan daun $H$. longiflora dimasukkan ke dalam tabung reaksi, tambahkan $1 \mathrm{ml} \mathrm{HCl} 2 \mathrm{~N}$ dan $6 \mathrm{ml}$ aquadest, kemudian dipanaskan selama 2 menit, didinginkan, dan disaring. Filtrat diperiksa dengan dengan reagen Mayer terbentuk endapan putih.

Uji Daya Hambat Metode Disc Diffusion (Kirby Bauer) menurut Fatmalia dan Dewi (2018)

1. Buatlah suspensi bakteri dengan cara menginokulasikan sampel bakteri ke dalam $\mathrm{NaCl}$ 0,9\% steril kemudian homogenkan dan bandingan kekeruhannya dengan standar McFarland 0,5 dengan menggunakan latar belakang hitam.

2. Inokulasikan suspensi bakteri dalam $\mathrm{NaCl}$ $0,9 \%$ tersebut ke dalam media $\mathrm{MH}$ plate secara perataan dengan menggunakan kapas lidi steril kemudian inkubasi selama 15 menit.

3. Letakkan disk antibiotik kontrol positif (kloramfenikol $30 \mu \mathrm{g}$ ), kontrol negative (aquadest steril), dan blank disk antibiotik yang telah dicelupkan kedalam air rebusan daun $H$. longiflora dengan masing - masing konsentrasi 20\%, 40\%, 60\%, 80\%, 100\% pada media tersebut secara aseptis.

4. Inkubasi pada suhu $37^{\circ} \mathrm{C}$ selama 24 jam.

5. Amati terbentuknya zona radikal yang terbentuk kemudian ukur zona yang terbentuk dengan menggunakan jangka sorong dan nyatakan dalam satuan milimeter.

6. Lakukan pengulangan sebanyak 4 kali.

\section{Teknik Analisa Data}

Data yang didapatkan dari penelitian diolah menggunakan Microsoft Excel dan disajikan dalam bentuk tabel maupun diagram batang.

\section{Hasil Dan Pembahsan}

Setelah dilakukan penelitian di laboratorium bakteriologi STIKES NASIONAL pada bulan Februari 2020 didapatkan hasil sebagai berikut : Hasil pengecatan Gram yang diamati dengan perbesaran 1000x didapatkan hasil bakteri dengan bentuk kokus, susunan bergerombol, sifat cat Gram positif, warna sel ungu dengan latar belakang merah. Pada media BAP didapatkan pertumbuhan koloni Staphylococcus aureus dengan bentuk bulat, ukuran sedang, warna koloni kuning emas.

\section{Uji katalase}

Uji katalase yang dilakukan mendapatkan hasil positif ditandai dengan terbentuknya gelembung gas.

Pengamatan pigmen dari media NA miring didapatkan koloni dengan pigmen kuning emas.

\section{Uji Manitol}

Uji manitol yang dlakukan didapatkan hasil positif yang ditandai dengan adanya perubahan warna media MSA dari merah menjadi kuning.

\section{Uji koagulase}

Uji koagulase yang dilakukan mendapatkan hasil positif, ditandai dengan terbentuknya aglutinasi.

\section{Uji fitokimia}

Hasil uji fitokimia rebusan daun $H$. longiflora yang dilakukan didaptakan hasil positif pada flavonoid dengan terbentuknya warna merah, uji saponin timbul busa yang stabil dalam 10 menit, dan uji alkaloid terbentuk endapan putih (Gambar 1).

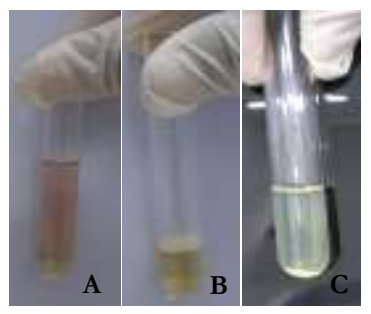

Gambar 1. Hasil uji fitokimia Rebusan

Daun Kitolod (Hippobroma longiflora): A.

Flavonoid, B. Saponin, C. Alkaloid 
Tabel 4. Zona Radikal Uji Daya Hambat Rebusan Daun Kitolod (Hippobroma longiflora) Terhadap Pertumbuhan Staphylococcus aureus

\begin{tabular}{cccccccc}
\hline \multicolumn{7}{c}{ Konsentrasi Rebusan } \\
Zona Radikal $(\mathrm{mm})$ \\
\hline Ulangan & Kontrol (-) & $20 \%$ & $40 \%$ & $60 \%$ & $80 \%$ & $100 \%$ & Kontrol (+) \\
\hline I & 6,00 & 6,20 & 6,20 & 7,50 & 7,50 & 8,70 & 26,20 \\
II & 6,00 & 6,10 & 6,10 & 6,20 & 6,70 & 7,70 & 26,60 \\
III & 6,00 & 6,20 & 6,20 & 6,30 & 7,30 & 8,20 & 26,10 \\
IV & 6,00 & 6,20 & 6,40 & 6,70 & 7,30 & 8,10 & 27,10 \\
\hline Rata-rata & 6,00 & 6,18 & 6,23 & 6,68 & 7,20 & 8,18 & 26,50 \\
\hline
\end{tabular}

Keterangan : zona radikal termasuk diameter disk $(6 \mathrm{~mm})$

Warna merah yang dihasilkan menandakan adanya flavonoid akibat dari reduksi oleh asam klorida pekat dan magnesium. Terbentuknya busa pada uji saponin terjadi karena saponin memiliki glikosil yang berfungsi sebagai gugus polar dan gugus steroid dan triterpenoid sebagai gugus nonpolar, senyawa yang memiliki gugus polar dan nonpolar bersifat aktif permukaan sehingga saat dikocok dengan air saponin dapat membentuk misel, pada struktur misel gugus polar menghadap ke luar sedangkan gugus nonpolarnya menghadap ke dalam, keadaan inilah yang tampak seperti busa. Pengendapan pada uji alkaloid terjadi karena adanya penggantian ligan. Atom nitrogen yang mempunyai pasangan elektron bebas pada alkaloid dapat mengganti ion iodo dalam pereaksi-pereaksi. (Sangi dkk, 2008).

\section{Uji Daya Hambat}

Berdasarkan tabel 4, kontrol positif yang digunakan adalah kloramfenikol $30 \mu \mathrm{g}$ terbentuk zona radikal dengan rata- rata $26,50 \mathrm{~mm}$. Kontrol negatif aquades steril tidak termasuk zona radikal karena pada dasarnya tidak memiliki sifat antibakteri sehingga tidak memunculkan zona radikal. Pada semua variasi konsentrasi terbentuk zona radikal. Data hasil perhitungan rata- rata zona radikal yang terbentuk dianalisis dengan menggunakan Microsoft Excel sehingga diperoleh diagram batang zona radikal rebusan daun $H$. longiflora terhadap pertumbuhan $S$. aureus.

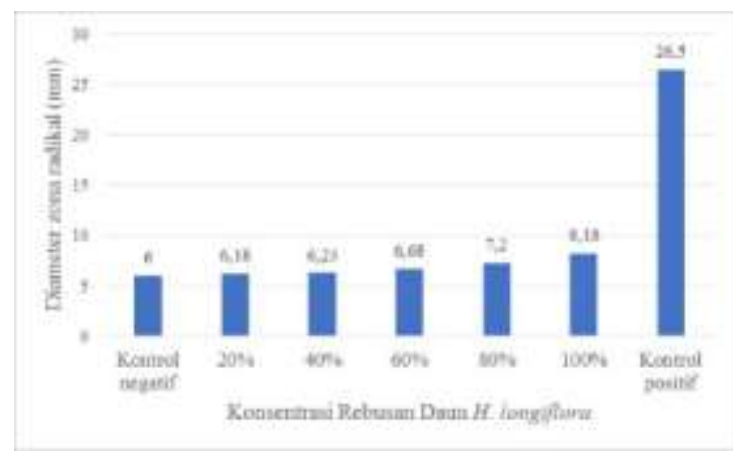

Gambar 1. Diagram Batang Zona Radikal Rebusan Daun $H$. longiflora Terhadap Pertumbuhan $S$. aureus

Grafik di atas menunjukkan bahwa semakin tinggi konsentrasi rebusan daun $H$. longiflora maka semakin lebar zona radikal yang dihasilkan.

Pengamatan hasil karakterisasi kultur murni S. aureus yang didapatkan dari Laboratorium Bakteriologi STIKES NASIONAL didapatkan hasil bakteri Gram positif berbentuk kokus, sel bakteri berwarna ungu. Dewi, (2013) dalam penelitiannya menjelaskan bahwa perbedaan sifat Gram dipengaruhi oleh kandungan pada dinding sel, yaitu bakteri Gram positif kandungan peptidoglikan lebih tebal jika dibanding dengan Gram negatif.

Uji katalase $S$. aureus menunjukkan hasil positif. Fungsi uji katalase pada bakteri berbentuk kokus adalah untuk membedakan antara Staphylococcus dan Streptococcus, dimana kelompok Staphylococcus bersifat katalase positif. Katalase merupakan enzim yang mengkatalisa penguraian hidrogen peroksida menjadi $\mathrm{H} 2 \mathrm{O}$ dan O2. Hidrogen peroksida bersifat toksik 
terhadap sel karena bahan ini menginaktifkan enzim dalam sel. Hidrogen peroksida terbentuk sewaktu metabolisme aerob, sehingga mikroorganisme yang tumbuh dalam lingkungan aerob pasti menguraikan bahan tersebut (Dewi, 2013).

Pada uji fermenteasi manitol memberikan hasil positif dengan ditandainya perubahan warna media MSA dari merah menjadi kuning. Perubahan media terjadi karena bakteri mampu memfermentasi karbohidrat menghasilkan asam sehingga dapat menurunkan $\mathrm{pH}$, dengan demikian warna indikator berubah. Kemampuan mikroba memfermentasikan karbohidrat sangat bervariasi dan hasil biooksidasi dalam fermentasi karbohidrat pun bermacam-macam. Produksi asam dari karbohidrat dapat terjadi pada kondisi aerobik maupun anaerobik. Karakteristik fermentasi karbohidrat sering dipakai untuk membedakan spesies bakteri dalam satu genus tertentu untuk tujuan identifikasi (Karimela dkk, 2017).

Hasil koagulase positif dengan ditunjukkan adanya aglutinasi. Uji koagulase bertujuan untuk mengetahui kemampuan bakteri menghasilkan enzim koagulase. Produksi koagulase adalah kriteria yang paling umum digunakan untuk identifikasi sementara $S$. aureus. Reaksi koagulase positif sangat penting untuk membedakan $S$. aureus dengan spesies Staphylococcus yang lain (Dewi, 2013).

Aktivitas penghambatan pertumbuhan $S$. aureus oleh rebusan daun $H$. longiflora karena adanya senyawa fitokimia. Dalimartha (2008) menyatakan bahwa tanaman $H$. Longiflora mengandung senyawa fitokimia seperti flavonoid, saponin, dan alkaloid. Hal ini juga dibuktikan dengan hasil skrining fitokimia yang dilakukan peneliti yang menunjukkan hasil positif. Senyawa flavonoid dan saponin menghambat pertumbuhan bakteri dengan mendenaturasi protein sel dan merusak membran sitoplasma. Sedangkan alkaloid memiliki kemampuan sebagai antibakteri dengan cara mengganggu komponen penyusun peptidoglikan pada sel bakteri sehingga lapisan dinding sel tidak terbentuk secara utuh (Apriani dkk, 2014).
Kontrol positif yang digunakan adalah kloramfenikol $30 \mu \mathrm{g}$ yang merupakan antibiotik berspektrum luas. Menurut CLSI (2019) kloramfenikol dikatakan sensitif apabila terbentuk zona radikal $\geq 18 \mathrm{~mm}$, resisten apabila terbentuk zona $\leq 12 \mathrm{~mm}$, dan intermediet apabila terbentuk zona 13-17 $\mathrm{mm}$. Uji daya hambat rebusan daun $H$. longiflora ini merupakan penelitian eksperimental yang bertujuan untuk mengetahui apakah daun $H$. longiflora memiliki aktivitas terhadap pertumbuhan $S$. aureus sehingga membentuk zona radikal yang besarnya zona diukur menggunakan jangka sorong. Kandungan senyawa antibakteri dalam daun $H$. longiflora membentuk zona radikal mulai dari konsentrasi $20 \%$. Dengan membandingkan hasil zona radikal rebusan daun $H$. longiflora pada konsentrasi $100 \%$ dengan kontrol positif berarti zona radikal yang terbentuk dalam menghambat pertumbuhan $S$. aureus tidak sebanding dengan kriteria sensitif terhadap antibiotik kloramfenikol $30 \mu \mathrm{g}$. Aktivitas antibakteri dapat dipengaruhi oleh beberapa faktor yaitu konsentrasi ekstrak, kandungan senyawa antibakteri, daya difusi ekstrak dan jenis bakteri. Adanya penambahan konsentrasi maka kandungan senyawa antibakterinya akan semakin besar sehingga semakin banyak pula senyawa antibakteri yang berdifusi ke dalam sel bakteri dengan mekanismenya masing-masing dan zona hambat juga semakin besar (Dewangga dan Qurrohman, 2019).

Kandungan zat bioaktif dapat dipengaruhi oleh suhu (Puspitasari dkk, 2019). Dalam penelitian ini pemanasan menjadi pengaruh terbesar terhadap mekanisme kerja metabolit sehingga diameter zona radikal yang terbentuk pada masing-masing konsentrasi tidak terlalu maksimal. Hal ini dapat dipicu karena banyaknya metabolit yang menguap selama proses pemanasan sehingga mekanisme dalam menghambat pertumbuhan $S$. aureus kurang maksimal. Hal inilah yang menyebabkan zona radikal yang terbentuk jauh dari zona radikal kontrol positif. Rebusan daun $H$. longiflora memberikan pengaruh terhadap pertumbuhan $S$. aureus dimana semakin tinggi konsentrasi semakin besar pula daya antibakteri yang dihasilkan karena kandungan zat aktif yang dimiliki. 


\section{Kesimpulan}

1. Rebusan daun H. longiflora mampu membentuk zona radikal pada semua konsentrasi terhadap pertumbuhan Staphylococcus aureus.

2. Zona radikal yang dihasilkan oleh rebusan daun $H$. longiflora tidak melebihi zona radikal dari kontrol positif.

\section{Ucapan Terimakasih}

Terimakasih atas bantuan dan dukungan berbagai pihak, rekan penelitian, dosen pembimbing, dan Sekolah Ilmu Kesehatan Nasional

\section{Referensi}

Abdurrauf, M. 2016. Memutus Mata Rantai Penularan Konjungtivitis Bakteri Akut. Idea Nursing Jurnal. 7 (2). ISSN:2087-2879

Ampou, E, E., Triyulianti, I dan Nugroho, S, C. 2015. Bakteri Asosiasi Pada Karang Scleractina Kaitannya Dengan Fenomena La-Nina Di Pulau Bunaken. Jurnal kelautan nasional. 10 (2): 55-63

Apriani,D., Amaliawati, N., dan Kurniati, E. 2014. Efektivitas Berbagai Konsentrasi Infusa Daun Salam (Eugenia polyantha Wight) terhadap Daya Hambat Bakteri Staphylococcus aureus Secara In Vitro. Jurnal Teknologi Laboratorium. $3(2)$

CLSI (Clinical and Laboratory Standards Institute). 2019. Performance Standards For Antimicrobial Susceptibility Testing. USA: Twenty - Sevenft Informational Supplement.

Dalimartha, S. 2008. Atlas Tumbuhan Obat Indonesia. Jilid 5. Jakarta : Pustaka Bunda

Dewangga,V.S.,Qurrohman,M.T. 2019. Potensi Antibakteri Ekstrak Etanol Herba Meniran Hijau (Phyllanthus niruri Linn.) Dalam Menghambat Pertumbuhan Staphylococcus aureus. Jurnal Kesehatan Kusuma Husada : 144-150

Dewi, A.K. 2013. Isolasi, Identifikasi dan Uji Sensitivitas Staphylococcus aureus Terhadap Amoxicillin Dari Sampel Susu Kambing Peranakan Ettawa (PE) Penderita Mastitis Di Wilayah Girimulyo Kulonprogo Yogyakarta. Jurnal Sain Veteriner. 31 (2): 138-150. ISSN: 01260421
Fatmalia, N., Dewi, E.S.2018. Uji Efektivitas Rebusan Daun Suruhan (Peperomia pellucida) Terhadap Pertumbuhan Bakteri Staphylococcus aureus. Jurnal Sains. 8 (15): 8-15. ISSN: 2087-0725

Ilyas, S.2014. Ilmu Penyakit Mata.Jakarta: Balai Penerbit Fakultas Kedokteran Universitas Indonesia

Insani, M.L., Adioka, I.G.M, Artini, I.G.A., Mahendra, A.N. 2017. Karakteristik Dan Manajemen Konjungtivitis Pasien Rawat Jalan Di Rumah Sakit Indra Denpasar Periode Januari - April 2014.E-Jurnal Medika. 6 (7): 1-6

Jawetz, Melnick, dan Aldenberg. 2013. Mikrobiologi Kedokteran. Jakarta: Penerbit Buku Kedokteran. EGC

Karimela, E.J., Ijong, F.G., Dien, H.A. 2017. Karakterisasi Staphylococcus aureus Yang Diisolasi Dari Ikan Asap Pinekuhe Hasil Olahan Tradisional Kabupaten Sangihe. JPHPI. 20 (1)

Kuswiyanto. 2016. Bakteriologi 1 Buku Ajar Analis Kesehatan. Jakarta : Penerbit Buku Kedokteran. EGC

Malik,E. \& Dewi,M. 2014. Perasan Daun Kitolod Terhadap Daya Hambat Pertumbuhan Bakteri Staphylococcus aureus Secara In Vitro. Jurnal Farmasetis. $3(2): 37-41$

Nirwana, A.P., Astirin, O.P, Widiyani, T. 2015. Skrining Fitokimia Ekstrak Etanol Benalu Kersen (Dendrophtoe pentandra L. Miq.). El Vivo. 3 (2) : 9-15. ISSN : 2339-1901

Puspitasari, D., Desrita. 2019. Pengaruh Metode Perebusan Terhadap Uji Fitokimia Daun Mangrove Excoecaria agallocha. Acta Aquatica: Aquatic Sciences Journal. p-ISSN. 2406-9825 eISSN. 2614-3178

Richards, A., Guzman-Cottril, JA. 2010. Pediatrics in Review Volume 31 (5)

Sangi, M., Runtuwene, MRJ., Simbala, HEI., Makang VMA. 2008. Analisis Fitokimia Tumbuhan Obat Di Kabupaten Minahasa Utara. Chemistry Progress Vol. 1, No. 1 (47-53)

Septiani, N.D., Eko,Wijayanti, Ima. 2017. Aktivitas Anti Bakteri Ekstrak Lamun (Cymodocea rotundata) Terhadap Bakteri Staphylococcus aureus Dan Escherichia coli. Saintek Perikanan Volume 13, Nomor 1-6. 